\title{
Common External Tariff and Dynamism of Economic and Regional Integration in the WAEMU Zone: An Analysis Based on the Econometric Approach of Panels
}

\author{
Zahore Gnoleba Martin ${ }^{1}$ \\ ${ }^{1}$ Deparment of Economics and Development, University Alassane Ouattara of Bouaké, Côte d'Ivoire \\ Correspondence: Zahore Gnoleba Martin, Deparment of Economics and Development, University Alassane \\ Ouattara of Bouaké, Côte d'Ivoire. E-mail: lagnol2000@yahoo.fr
}

Received: July 26, 2016

Accepted: September 1, $2016 \quad$ Online Published: September 20, 2016

doi:10.5539/ijbm.v11n10p224

URL: http://dx.doi.org/10.5539/ijbm.v11n10p224

\begin{abstract}
This article discusses the implications of the introduction of the Common External Tariff on the dynamism of economic and regional integration in the WAEMU zone. The sample includes eight countries and covers the period from 1990 to 2014. The study is based on the econometric approach of panels. The results suggest that the common external tariff has significantly contributed to strengthen the dynamism of the economic and regional integration in the Economic and Monetary Union of West Africa. These results show that the WAEMU countries have an interest in developing new Community mechanisms conducive to strengthen the integration within them.
\end{abstract}

Keywords: common external tariff, economic and regional integration, UEMOA, panel, ADF, MCG, poolability, OLS, autocorrelation, normality

\section{Introduction}

Regional integration remains the key strategy that will enable African governments to accelerate the transformation of their fragmented small economies, to expand their markets, to extend the continental economic space and to reap the benefits of economies of scale in benefit of the production and trade, by increasing the maximum prosperity for their nations (Krugman, 2010). Regional integration improves competitiveness in world trade and access to technology, investment and ideas from abroad (BALASSA, 1966). African leaders therefore consider, for their part, regional integration as an important step towards a broad-based development and to the establishment of a regional economic community, according to the (Treaty Establishing the African Economic Community, 1991) the Constitutive Act of the (African Union, 2000). Regional integration in Africa results from the political will of the countries since independence to ensure greater opportunity for the integration of economies in the global market (DWIGHT, 2011). It is true that regional integration must go through the strengthening of the legal and institutional framework, but if that technical device does not coincide with real economic integration, it is obvious that regional integration structure will appear as an empty shell (Gillis, 2008). It is therefore essential to develop in parallel to the process of regional integration, an economic integration. Among Intergovernmental Organizations in West Africa, one of the most important is the Economic and Monetary Union of West Africa (WAEMU) which forms a monetary and customs union with the CFA franc as a common currency and whose member countries are: Benin, Burkina Faso, Côte d'Ivoire, Guinea Bissau, Mali, Niger, Senegal and Togo. The establishment of a comprehensive integrated regional market offers many opportunities including the ability to absorb external shocks that would otherwise have adverse effects on major individual level (ALLEGRET, 2008). Also, regional integration does play an important role in the growth and development (RICARDO, pp. 1772-1823). This process is well under way at the Economic and Monetary Union of West Africa (WAEMU). The Treaty signed in Dakar in January 1994 and establishing WAEMU is the act of major economic policy laid down by the Conference of Heads of Member States of the WAMU in support of the change in the parity of the CFA franc. It was created between the Member States (Article 4 of the Treaty), a common market, based on the free movement of persons, goods, services, capital and the right of establishment for self-employed persons or employee. The Customs Union is one of the pillars and appears as the result of a long process that began in 1996 with a series of reforms to liberalize intra-Community trade, and culminated on 1st January 2000 to the establishment a Common External Tariff (CET). The term common external tariff refers to the implementation in the Member States of a customs union of the same tariff to goods from third countries. 
In other words, the common external tariff of the WAEMU is the uniform rate of Member States and which is applied to goods from non-member countries. It comes to replace the various national rates. The implementation of reforms, related to the establishment of the external tariff among WAEMU countries, was implicitly directed towards the adoption of a common tariff and statistical nomenclature that is to say the same designation system and Coding one hand goods to and from the application to goods originating in third countries the same entry rights or rights holder or the other tariffs. When the political authorities of eight (8) WAEMU member states decided in 1994 through the Treaty in Article 4 of the establishment of a common external tariff for the purpose of achieving the realization of a common market, they certainly had the ambition to develop an integrative instrument of the economies of eight (8) member states; instrument that should enable them eventually to achieve the objectives of economic and social development. But since 1st January 2000, official date of entry into force of the CET WAEMU, the States still do not seem to have reached the level of economic and social development as desired. So the central question that this study seeks to answer is: the establishment of the CET in WAEMU competed or not to strengthen the dynamism of the integration of eight (8) member states Economic and Monetary Union of West Africa?

From the above the goal of this study is to empirically assess the effects of the introduction of the Common External Tariff on the dynamism of the regional economic integration of the countries of the WAEMU.

This will be specifically for us to see if the WAEMU CET has helped to significantly improve the well-being of populations and the increase of the GDP of Member States of the Union. The study uses the GCM method on a homogeneous panel data. This method is applied in five (5) different equations representing important indicators of development of WAEMU States. The advantage of the MCG is to correct a possible heteroscedasticity of residuals.

The rest of the article is as follows: the literature review will be subject of the section 2 . The data description and definition of the variables used in this study will form the frame of section 3. In addition the presentation of the methodology will be done in Section 4 and in Section 5 will follow the presentation of results. Section 6 for its part will focus on concluding and economic policy implications.

\section{Literature Review}

The theory of trade or international trade developed by (Adam Smith, pp. 1723-1790) and (David Ricardo 1772-1823), teaches that only "laissez-faire" and free trade are capable of ensuring economic efficiency world level. Regional integration agreements have long been considered as free trade agreements. Thus, trade liberalization in the nineteenth century is often illustrated by the Cobden-Chevalier 1860 agreement, free trade treaty between England and France. According to (Mussa, 2013) three basic factors influence the process of economic integration: technology, preferences and public policy. According to (Mwamadzingo, 2001) development requires the organization of economic and social activities on a much larger scale than what is currently found in various countries in Africa. Indeed, most African countries are relatively small, not only in terms of population but also in economic performance. This situation is an invitation to regional integration as a major strategy to promote regional trade, accelerate development, promote structural changes, to enable the African continent to overcome its problems of economic fragmentation and promote economic diversification. As for (Grossman \& Helpman, 1994), integration with the world economy can boost productivity of a country. Firstly, residents of a country integrated into global markets can access to broader technological knowledge as those countries who live in relative isolation, because trade contributes to the diffusion of technology. Secondly, exposure to international competition may lessen the risks of industrial research duplication. If a company that produces a product for the domestic market does not need to use that new technology only in the local economy, another one that hopes to enter successfully the competition imposed by international market, will be forced to find truly innovative ideas on a global scale. Thirdly, by expanding the potential customer base, international integration may encourage further industrial research. According to (Blanke, 2013), Africa's growth should be seen in a wider international context, where gains encouraging economic growth contradict the underlying weakness of its long-term competitiveness. Regional integration is the key to overcome the economic decline of Africa by bringing wider economic and social benefits. It should be considered as a priority by African leaders who want to reach the stage of emergence. Because it allows access to technology, investment, ideas from abroad and improve competitiveness in global trade, economic integration is a likely way to develop trade among African countries and with the rest of the world. The empirical evaluation of the relationship between trade and growth is inconclusive. Some studies have led to a positive correlation between trade and growth, whereas others have come to the conclusion that the reduction of trade barriers produces a negative effect. (Scitovski \& Scott, 1970) and (Balassa, 1971) were the first to focus on the subject. Since then, many economists have tried to establish a link between variables of trade policy and economic growth. Initial studies undertaken by (Dollar, 
1992), (Sachs \& Warner, 1995) consisted of comparative regression analysis covering several countries. They have found positive correlations between the degree of openness of a country and the speed of economic growth. (Wacziarg \& Welch, 2003) confirm the conclusion that trade liberalization has a positive effect on growth, they fix the date of opening the trade regime for each of the 133 countries targeted for study and find that growth in countries that have opted for trade liberalization was during the period following the opening on average $1.4 \%$ higher than in the period before liberalization. As for Sachs and (Warner, 1995), they concluded that the annual growth in open economies exceeds that of the most closed economies of 2 to $2.5 \%$. In addition, (Francis \& Schuknecht, 1999) argue that trade opening has the effect to strengthen the competitiveness, which promotes economic growth by a percentage of the same order. (Baldwin, 2003) also demonstrated convincingly that countries where there are few restrictions to trade manage too faster economic growth than countries where more restrictive policies are applied. With regard to this theoretical evaluation that attests the positive link between trade openness and economic growth, we shall therefore continue this empirical analysis between commercial openness and poverty. According to (Dollar \& Kraay, 2002), the opening of trade creates a pro-poor growth. As for (Winter, McCulloch, \& McKay, 2004), it is possible to reduce poverty through long-term economic growth. They also argue that faster economic growth helps to raise income levels, which in return allows governments to levy more tax revenue to take distributive measures. As for (Winters, 2002), it has also shown that trade can influence poverty through various channels (economic growth, price development, sales revenue in the market, government revenues). Since poverty is reduced more rapidly when growth is faster, poor countries could use trade liberalization as an instrument of their policies. Trade liberalization reduces the relative price distortions and allows the activities with comparative advantages to be developed with the view to boost economic growth. Because poverty is the greatest challenge that Africa faces, analysis of the link between trade and poverty is of crucial importance as reducing the effects of poverty is the fundamental objective of current development policies.

According to (Krugman, 2003), the history shows that poor countries that were able to improve the living standards of their populations have achieved through globalization, because they chose to produce for the world market rather than seeking to be sufficient in themselves. However (Rodriguez, 1999) and (Rodrik, 2001) have questioned these results, because the opening is probably a consequence rather than a precondition for growth. Moreover, for (Winters, 2004), three difficulties can be encountered when trying to establish an empirical link between trade and economic growth. Firstly, for countries that do little or no trade with the outside world, it is very difficult to measure the state of their trade. Secondly, trade liberalization alone does not guarantee a lasting effect on growth. It must be combined with other structural policies. Thirdly, it is very difficult to establish causation. Moreover (Rodriguez \& Rodrik, 2000) show that the results are better for growth when there is use of protectionist trade regimes. Indeed, comparative studies between regressions several countries indicate that trade liberalization is not sufficient in itself to stimulate growth and reduce poverty. The reforms must be supported by appropriate and effective policies in the fields of education, macroeconomic stability and infrastructure. Trade policies are an arrogance in any initiative of regional trade agreement, tariff regimes must be applied appropriately. By analyzing the work of (Sachs \& Warner, 2003), (Berg \& Krueger, 2003) find confirmation of the idea that a positive correlation exists between trade policy and economic growth. They conclude that, though, and it must be admitted, the influence of trade policy is difficult to measure the conducted policy, there is no need to conduct such a measure in order to rule in favor of political Trade opening. Other researchers have found positive effects on growth, using the index (Sachs \& Warner). Based on data for 84 countries from 1960 to 2000, (Bosworth \& Collins, 2003) conducted a regression estimate of growth of per capita income on the initial per capita income, human capital as indicated the life expectancy of the first year, changing terms of trade, institutional quality, geography (number of frost days and extent of the tropical zone), the evolution of inflation, budget balance and openness. Their coefficient on the Sachs and Warner variable shows a statistically significant increase of 0.82 percentage points of growth per capita in open economies with respect to closed economies. The two authors argue that the influence of trade openness on growth comes from capital deepening rather than assuming Sachs and Warner, that there has been a change in total factor productivity. (Michalopoulos, 1999) indicates that most developing countries have different tariff structures with significant escalation tariffs. This tariff escalation is used for certain purposes, for reasons of substitute imports and to spare the cash activities of some interested parties. As for (Ukaoha, 2008), he recalled that the levels of import prices are inversely proportional to the level of economic development. In addition, (Tarr, 2001) points out that it is advantageous for countries to impose uniform tariffs; uniform tariffs simplify customs operations, eliminate corruption and preserve scarce administrative resources. They also encourage the few entrepreneurial talents to work more productively, by making better and cheaper products. For (Thugge \& Bannister, 2001) the existence of uniform tariffs does not necessarily mean that no exception could exist. Products considered to be crucial to the health 
such as essential medicines and mosquito nets, would be exempt. Some studies have shown that regional trade agreements in Africa have not been the source of increased trade (Elbadawi, 1997). For (Diouf, 2002), the failure of African regional agreements is looking into the option of a process of integration by the market at the expense of physical integration. As for (Sylla, 2003) the failure of integration in Africa is due to the selfishness of rulers jealous of the sovereignty of their states judged to be unsustainable in the context of globalization. But Cernat (2001) finds empirical evidence to support the fact that free trade areas and customs unions boost African trade not only within the continent, but also with non-African countries. Elbadawi (1997) argues in the same way as the expansion of regional markets, which typically accompany training African trading blocs, may create sufficient economies of scale can lead to complementarities and diversity in production as desired between Member States of such unions. In a similar analysis, Lewis et al. (1999) and Evans (1998) arrived at the conclusion that the southern African regional integration schemes produced significant and positive net effects in the field of economic prosperity. The regional integration process initiated in the West African States has led some authors to bring reflections on the policy, among which was (BA, 2003), who did a study on the assessment of trade policies as part of the integration process in West Africa. His study is to provide an analysis of trade policies implemented by each of the fifteen member states of the Economic Community of West African States (ECOWAS) with the trade policy objectives of this community to determine the intensity of the regional integration process. The first part of his study analyzes the trade policies of member states, appreciate and evaluate their effects on trade flows. The second part of the same study is devoted to the analysis of the trade liberalization program of ECOWAS, in its design, implementation, and evaluation of the effects of opening policies on trade, public finance, and consumers in the Member States. As for (Peter \& Baris, 2005), they carry their study on the evaluation and analysis of the impact of tariff disarmament measures being considered by Guinea on agriculture and agro-industry food in the discussions within the ECOWAS harmonization of tariffs with those of WAEMU. From this evaluation and analysis, it is therefore enable Guinea to define better its negotiating positions on agriculture and agro-food. As it can be seen no analysis has been undertaken on the real or supposed effects of the introduction of CET of WAEMU on the dynamism of integration in this area; and this study would be a contribution to fill that void.

\section{Description of Data and Definition of Variables}

The analysis covers the eight (8) WAEMU countries and covers the period $1990-2014$. This is a homogeneous panel data. This study is based on data from the database WDI (World Development Indicators) of the World Bank and data BECEAO. To try to answer the central question posed, the key variables used are as follows:

\begin{tabular}{lll}
\hline variables & Definitions & Expected sign \\
\hline$\left(I N F_{i t}\right)$ & this variable captures the evolution of the price index in each member of WAEMU zone & negative \\
$\left(R N B_{i t}\right)$ & gross national income per capita of countries in the region & positive \\
$\left(\boldsymbol{E} \boldsymbol{X} \boldsymbol{P}_{i t}\right)$ & the total volume of exports from countries in the region & positive \\
$\left(\boldsymbol{G D} \boldsymbol{P}_{i t}\right)$ & the evolution of wealth in each WAEMU country & positive \\
$\left(\boldsymbol{D E} \boldsymbol{F}_{i t}\right)$ & The budget deficit of the WAEMU countries & positive \\
$\mathbf{T E C}_{i t}$ & Common External Tariff & positive \\
\hline
\end{tabular}

Note. All variables are natural logarithm.

\section{Econometric Methodology}

We will present the different stages of the econometric methodology to be adopted later in our study. Given the economic theory, we identified determinants of the dependent variables. So we end up with a theoretical-shaped with five equations of each country in the WAEMU zone.

\subsection{Presentation Model}

The theoretical model to estimate is:

$$
\begin{aligned}
& I N F_{i, t}=C_{i, t} \quad+\alpha_{i} \times L R N B_{i, t}+\beta_{i} \times G D P_{i, t}+\gamma_{i} \times C E T_{t}+\varepsilon_{i t} \\
& L R N B_{i, t}=C_{i, t} \quad+\alpha_{i} \times G D P_{i, t}+\beta_{i} \times L E X P_{i, t}+\gamma_{i} \times C E T_{t}+\varepsilon_{i t} \\
& G D P_{i, t}=C_{i, t}+\alpha_{i} \times I N F_{i, t}+\gamma_{i} \times C E T_{t}+\varepsilon_{i t} \\
& L E X P_{i, t}=C_{i, t} \quad+\alpha_{i} \times L G D P_{i, t}+\gamma_{i} \times C E T_{t}+\varepsilon_{i t} \\
& D E F_{i, t}=C_{i, t} \quad+\alpha_{i} \times L G D P_{i, t}+\gamma_{i} \times C E T_{t}+\varepsilon_{i t}
\end{aligned}
$$


Where:

$$
C E T_{t}=\left\{\begin{array}{c}
0 \text { si } t<2000 \\
1 \text { otherwise }
\end{array}\right.
$$

\subsection{Stationarity of Study Variables}

Since it is assumed an approach in panel data, stationary tests retained are those applicable to panel data. The literature has three groups of unit root tests in panel data. It will be presented succinctly few elements.

\subsubsection{The 1st Generation Tests}

These tests are based on the assumption of inter independence of residuals,

\subsubsection{Uniform Specification Autoregressive Root}

We have (Levin \& Lin tests, 1992, 1993) based on ADF tests (Augmented Dickey-fuller)

\subsubsection{Specifying the Heterogeneous Autoregressive Root}

We have (Im, Pesaran, \& Shin tests, 1997, 2002) also based on the ADF tests, the test of (Maddala \& Wu, 1999) which is a nonparametric, and the test of (Hadri, 2000), the null hypothesis is stationarity.

\subsubsection{The 2nd Generation Tests}

These tests take into account the possibility of inter-individuals dependencies of residuals.

\subsubsection{Tests Based on Factor Models}

We have (Bai \& Ng tests, 2001) and (Moon \& Perron, 2004), (Phillips \& Sul, 2003) and finally (Pesaran, 2003).

\subsubsection{Other Approaches}

In the over approaches we have (Chang, 2002, 2004) tests.

\subsubsection{The 3rd Generation Tests}

They take into account structurals changes in the study of stationarity. We have the tests of (Im \& Lee, 2001) and (Carrion, 2001, 2002). In the rest of our study, we will use the tests of (Shin, Im, \& Pesaran (Ipshin)) and (Levin $\&$ Lin (Levinlin)). The following table presents the results of stationarity tests.

Table 1. Stationarity tests

\begin{tabular}{lllllll}
\hline Tests & Type & LINF & LRNB & LGDP & LEXPL & LDEF \\
\hline IPSHIN & Model With Tendance & $-6.10^{* *}$ & -0.21 & $-7.4323^{* *}$ & $-2.60^{* *}$ & $-5.12^{* *}$ \\
& & $(0.0000)$ & $(0.9932)$ & $(0.0000)$ & $(0.0046)$ & $(0.0000)$ \\
& Model Without Tendance & $-5.34^{* *}$ & 6.14 & $-7.18^{* *}$ & 2.46 & $-3.06^{* *}$ \\
& & $(0.0000)$ & $(0.93)$ & $(0.0000)$ & $(0.9932)$ & $(0.0011)$ \\
LEVINLIN & Model With Tendance & $-5.15^{* *}$ & $-3.38^{* *}$ & $-8.98^{* *}$ & $-2.88^{* *}$ & $-2.48^{* *}$ \\
& & $(0.0000)$ & $(0.0004)$ & $(0.0003)^{*}$ & $(0.0020)$ & $(0.0066)$ \\
& & $-5.026^{* *}$ & 1.93 & $-2.53 * *$ & 0.28 & -1.53 \\
& Model Without Tendance & $(0.0000)$ & $(0.9737)$ & $(0.0056)$ & $(0.6129)$ & $(0.0626)$ \\
\hline
\end{tabular}

Source: Our calculations.

Note. $* *$ significance $1 \%$ and $5 \%$ significance $*$.

Afer the Stationarity tests we conclude that our series are stationary. Consequently, regressions can be done on these series without the risk of obtaining fallacious results.

\subsection{Checking the Panel Structure: Poolability Tests}

When considering a panel data sample, the first thing he should do is poolability test or test of specification or test of homogeneity of verifying the homogeneous or heterogeneous specification of the data generating process. Econometrically, this amounts to test the equality of the coefficients of the model studied in the individual dimension. In economic terms, the specification tests returned to determine if one is entitled to assume that the theoretical model studied is exactly the same for all countries, or if there are specifics elements to each country.

The results of the poolability test show us that our data favor the panel structure and that we are dealing with a totally homogeneous panel. 
Poolabilitity test

\begin{tabular}{llll}
\hline \multicolumn{2}{l}{ Test 1: equal coefficients and constants } & & \\
\hline & Hypothesis & Empirical Fisher & Decision \\
\hline Equation 1 & H0: the coefficients and constants are the same for all individuals & 0,540 & HO accepted \\
Equation 2 & H0: the coefficients and constants are the same for all individuals & 0,12 & HO accepted \\
Equation 3 & H0: the coefficients and constants are the same for all individuals & 0,056 & HO accepted \\
Equation 4 & H0: the coefficients and constants are the same for all individuals & 0,26 & HO accepted \\
Equation 5 & H0: the coefficients and constants are the same for all individuals & 0,054 & HO accepted \\
\hline
\end{tabular}

\begin{tabular}{llll}
\hline \multicolumn{2}{l}{ Test 2: equal coefficients } & & \\
\hline & Hypothesis & EmpiricalFisher & Decision \\
\hline Equation 1 & H0: the coefficients are the same for all individuals & 0,392 & HO accepted \\
Equation 2 & H0: the coefficients are the same for & 0,32 & HO accepted \\
Equation 3 & H0: the coefficients are the same for all individuals & 0,45 & HO accepted \\
Equation 4 & H0: the coefficients are the same for all individuals & 0,09 & HO accepted \\
Equation 5 & H0: the coefficients are the same for all individuals & 0,23 & HO accepted \\
\hline
\end{tabular}

\begin{tabular}{|c|c|c|c|}
\hline & Hypothesis & Empirical Fisher & Decision \\
\hline Equation 1 & H0: the constants are the same for all individuals & 0,85 & HO accepted \\
\hline Equation 2 & $\mathrm{H} 0$ : constants are the same for all individuals & 0,07 & HO accepted \\
\hline Equation 3 & H0: the constants are the same for all individuals & 0,23 & HO accepted \\
\hline Equation 4 & H0: the constants are the same for all individuals & 0,054 & HO accepted \\
\hline Equation 5 & H0: the constants are the same for all individuals & 0,26 & HO accepted \\
\hline
\end{tabular}

\subsection{Choice of Estimation Technique}

As we are in the presence of a homogeneous panel, we can use OLS (Ordinary Least Squares) or GCMs (Generalized Least Squares), GCMs have the advantage of correcting a possible heteroscedasticity of residuals, and we will use this method to estimate our different equations. Note that the model obtained after estimation is specified as follows:

$$
\begin{aligned}
& I N F_{i, t}=-3.95 L R N B_{i, t}+0.38 G D P_{i, t}+-5.22 C E T_{t}+30.92
\end{aligned}
$$

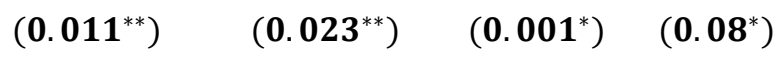

$$
\begin{aligned}
& L R N B_{i, t}=-0.0036 G D P_{i, t}+0.259 \operatorname{LEXP}_{i, t}+0.270 \text { CET }_{t}+4.32 \\
& \begin{array}{lll}
(0.492)\left(0_{000}^{* *}\right) & \left(0.000^{*}\right)\left(0^{0.003}{ }^{*}\right)
\end{array} \\
& \mathrm{PIB}_{\mathrm{i}, \mathrm{t}}=0.0636 \mathrm{INF}_{\mathrm{i}, \mathrm{t}}+1.541 \mathrm{CET}_{\mathrm{t}}+2.38 \\
& \left(0.025^{* * *}\right) \quad\left(0.013^{* *}\right) \quad(0.00 *) \\
& \mathrm{LEXP}_{\mathrm{i}, \mathrm{t}}=0.011 \mathrm{GDP}_{\mathrm{i}, \mathrm{t}}+0.603 \mathrm{CET}_{\mathrm{t}}+5.84 \\
& \left.\left(0.600^{* * *}\right)\left(0_{0.001}^{* *}\right)\left(0^{2.021}\right)^{*}\right) \\
& \mathrm{DEF}_{\mathrm{i}, \mathrm{t}}=1.61 \mathrm{GDP}_{\mathrm{i}, \mathrm{t}}-45.46 \mathrm{CET}_{\mathrm{t}}+-52.94 \\
& \left(\begin{array}{lll}
\left(0.324^{* * *}\right) & \left(0.038^{* *}\right) & \left(0.032^{*}\right)
\end{array}\right.
\end{aligned}
$$

Rating: (.) represents the associated p-value.

*** significance at $1 \%$ level, $* *$ significance at the $5 \%$ level, * Significance at the $10 \%$ threshold.

\subsection{Diagnosis of Regression}

It is important to ensure that the residues have good properties. The MCG has already corrected the possible heteroscedasticity of residuals, we do the autocorrelation and normality tests.

\subsubsection{Autocorrelation Test}

We test for autocorrelation of the residues with the Wooldridge test for panel data. The test results allow us to 
conclude in an autocorrelation of residue.

Diagnosis of errors

\begin{tabular}{lllll}
\hline \multicolumn{2}{l}{ Error autocorrelation test } & & & \\
\hline & Hypothesis & Fisher & Prob $>$ F & decision \\
\hline Equation1 & H0 : No autocorrelation & $\mathrm{F}(1,7)=3.938$ & Prob $>$ F $=0.0825$ & H0 accepted \\
Equation2 & H0: No autocorrelation & $\mathrm{F}(1,7)=2.756$ & Prob $>$ F $=0.0525$ & H0 accepted \\
Equation3 & H0: No autocorrelation & $\mathrm{F}(1,8)=3.834$ & Prob $>$ F $=0.0625$ & H0 accepted \\
Equation4 & H0: No autocorrelation & $\mathrm{F}(1,8)=1.934$ & Prob $>$ F $=0.0749$ & H0 accepted \\
Equation5 & H0: No autocorrelation & $\mathrm{F}(1,8)=6.0237$ & Prob $>$ F $=0.0925$ & H0 accepted \\
\hline
\end{tabular}

Source: Our calculations.

\subsubsection{Normality Test}

We use the normality of Shapiro-Wilk test for panel data to test the normality of residuals. The results allow us to conclude a normality of the regression residuals.

Equation 1

\begin{tabular}{|c|c|c|c|c|c|c|}
\hline \multicolumn{7}{|l|}{ Normality Test } \\
\hline Variable Residual & Obs & $\mathrm{W}$ & $\mathrm{V}$ & F & Prob $>f$ & decision \\
\hline Equation 1 & 200 & 0.93226 & 1.193 & 0.346 & 0.364 & Residual Normal \\
\hline Equation 2 & 200 & 0.98 & 2.85 & 2.4 & 0.21 & Residual Normal \\
\hline Equation 3 & 200 & 0.97 & 3.2 & 2.67 & 0.08 & Residual Normal \\
\hline Equation 4 & 200 & 0.81 & 28.04 & 7.67 & 0.07 & Residual Normal \\
\hline Equation 5 & 200 & 0.68 & 47.17 & 8.86 & 0.23 & Residual Normal \\
\hline
\end{tabular}

Source: Our calculations.

\section{Empirical Results}

The different equations obtained after estimation are as follows:

$$
\begin{aligned}
& \mathrm{INF}_{\mathrm{i}, \mathrm{t}}=-3.95 \mathrm{LRNB}_{\mathrm{i}, \mathrm{t}}+0.38 \mathrm{GDP}_{\mathrm{i}, \mathrm{t}}-5.22 \mathrm{CET}_{\mathrm{t}}+30.92 \\
& \begin{array}{llll}
\left(\mathbf{0 . 0 1 1}^{* * *}\right) & \left(\mathrm{0.023}^{* *}\right) \quad\left(\mathrm{O.001}^{*}\right) & \left(\mathrm{O.} \mathrm{08}^{*}\right)
\end{array} \\
& \mathrm{LRNB}_{\mathrm{i}, \mathrm{t}}=-0.0036 \mathrm{GDP}_{\mathrm{i}, \mathrm{t}}+0.259 \mathrm{LEXP}_{\mathrm{i}, \mathrm{t}}+0.270 \mathrm{CET}_{\mathrm{t}}+4.32
\end{aligned}
$$

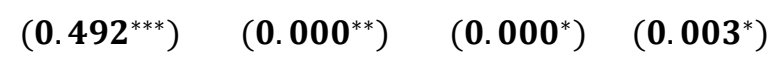

$$
\begin{aligned}
& \mathrm{GDP}_{\mathrm{i}, \mathrm{t}}=0.0636 \mathrm{INF}_{\mathrm{i}, \mathrm{t}}+1.541 \mathrm{CET}_{\mathrm{t}}+2.38 \\
& \left(\mathbf{0 . 0 2 5}^{* * *}\right) \quad\left(\mathbf{0 . 0 1 3}^{* *}\right) \quad\left(\mathbf{0 . 0 0}^{*}\right) \\
& \operatorname{LEXP}_{\mathrm{i}, \mathrm{t}}=0.011 \mathrm{GDP}_{\mathrm{i}, \mathrm{t}}+0.603 \mathrm{CET}_{\mathrm{t}}+5.84 \\
& \left(\mathbf{0 . 6 0 0}^{* * *}\right) \quad\left(\mathbf{0 . 0 0 1}^{* *}\right) \quad\left(\mathbf{0 . 0 2 1}^{*}\right) \\
& \mathrm{DEF}_{\mathrm{i}, \mathrm{t}}=1.61 \mathrm{GDP}_{\mathrm{i}, \mathrm{t}}-45.46 \mathrm{CET}_{\mathrm{t}}-52.94
\end{aligned}
$$

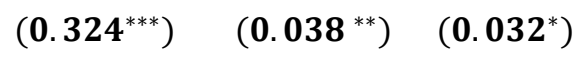

The estimation of the five (5) equations that make up our econometric model gives us the following observations:

The implementation of the common external tariff has a significant beneficial effect on the level of inflation. In other words the entry into force of the CET has helped to reduce the inflation rate of the countries of the zone. Indeed it should be noted that the WAEMU CET concludes a protection tax that aims to correct a possible eviction of local products by massive imports from third countries. Thus, the TEC has reduced imported inflation through a reduction in imports that led to a fall in inflation ceteris paribus (Equation 11).

The adoption of the WAEMU CET also helped boost exports from countries in the area. Indeed the harmonization of taxes between countries helped boost exports through lower export taxes (Equation 14). 
The adoption of the CET has a positive effect on the GDP of the WAEMU. It has increased the wealth generated by the countries of the zone. Indeed protection tax contained in the CET has enabled the industries that suffered competition from imported goods to rise and produce more. Also what was believed to be a risk of polarization effect in favor of Ivory Coast has instead turned to all companies in the area regardless of their geographical location thanks to the CET (equation 13).

Equation 12 gives us to see an increase in the gross national income per capita; increase that is itself a result of the increase in gross domestic product of each of the states in the area following the introduction of CET.

Equation 15 reveals that the introduction of the CET has considerably reduced the budget deficit of the WAEMU countries through increased government revenues that it promotes through increased production enterprises.

\section{Economic Policy Conclusions and Implications}

The objective of this study was to empirically assess the implications of the adoption of the Common External Tariff by the WAEMU countries on the dynamism of economic and regional integration in this area. To achieve this goal, we estimated five (5) equations representative of the main indicators of development of the countries in this zone: gross domestic product; the budget deficit; the inflation rate, the volume of exports and gross national income per capita, by the method of generalized least squares (GLS).

Our results reveal that the adoption of the CET in WAEMU was generally beneficial for the countries of this union given the expected signs from different coefficients of different estimates and their significance to the various selected thresholds. That said it appears more than important that the WAEMU countries pursue bold reforms in the CET to further strengthen the substantial gains from the harmonization of fiscal and trade policies.

\section{References}

Alemayehu, G., \& Haile, K. (2008). Regional Integration in Africa: A Review of Problems and Prospects with a Case Study of Comesa. Journal of African Economies.

Anderson, J. E., \& Eric, V. W. (2003). Gravity with Gravitas: A Solution to the Border Puzzle. American Economic Review.

Balassa, B. (1966). Tarrif reductions and trade in manufacture among in the industrial countries. American Economic Review, 466-473.

Balassa, B. (1971). The Structure of Protection in Developing Countries, Baltimore. MD: Johns Hopkins University Press. http://dx.doi.org/10.2307/1238366

Baldwin, R. (2003). Openness and growth: What's the Empirical Relationship? NBER Working Paper 9578. http://dx.doi.org/10.3386/w9578

Boubacar, B. (2003). Etude sur la compatibilité des politiques commerciales dans le cadre du processus d'intégration en Afrique de l'Ouest, Mars 2003.

Carrère, C. (2004). African Regional Agreements: Impact on Trade with or without Currency Unions. Journal of African Economies, 13(2). http://dx.doi.org/10.1093/jae/ejh010

Deardorff. (1998). Cité dans État de l'intégration régionale en Afrique IV Développer le commerce intra-africain, Commission Economique pour l'Afrique, Addis-Abeba.

Dollar, D. (1992). Outward-Oriented Developing Economies Really Do Grow More Rapidly: Evidence from 95 LDCs. Economic Development and Cultural Change, 40. http://dx.doi.org/10.1086/451959

Dollar, D., \& Kraay, A. (2002). Growth is Good for the Poor, World Bank Policy Research Working Paper.

Elbadawi, I. (1997). The Impact of Regional Trade and Monetary Scheme on Intra-Sub-Saharan African Trade, Regional Integration and Trade Liberalization in Sub-Saharan Africa, Volume I: Framework, Issues and Methodological Perspectives. Londres: Macmillan.

Foroutan, F., \& Lant, P. (1993). Intra-Sub-Saharan African Trade: Is it too Little? Journal of African Economies.

Frankel, J., \& Rose, A. (2002). Estimating the Effect of Currency Unions on Trade and Output. Quarterly Journal of Economics, 17. http://dx.doi.org/10.1162/003355302753650292

Guillaumont, S. (2002). Le Bilan de l'Intégration Monétaire dans l'UMOA. Actes du Symposium du Quarantième Anniversaire de la BCEAO, 1.

Khavand, F. A. (2001). Commerce International: Le Régionalisme menace t-il l'Universalisme? Institut international d'études stratégiques, Paris. 
Krugman, P., \& Obtefeld, M. (2010). Economie internationale, Nouveaux horizons (8th éd.).

Little, I., Scitovski, T., \& Scott, M. (1970). Industry and Trade in Some Developing Countries. Oxford University Press. http://dx.doi.org/10.2307/2229769

Perkin, S. D. H., Radelet, S., \& Lindauer, D. L. (2011). Economie du développement, Nouveaux horizons de boeck (3rd ed.).

Pierre, B., Arlène, A. (2005). Impact des désarmements tarifaires sur l'agriculture et l'agroalimentaire, Dynafiv.

Rodriguez, F., \& Rodrik, D. (1999). Trade Policy and Economic Growth: A Skeptic's Guide to the Cross-National Evidence. NBER Working Paper.

ROPPA, O. (2008). Note de travail relative à la réforme du Tarif extérieur commun de la CEDEAO, rédigée à la demande d'OXFAM international et du ROPPA.

Rose, A. K. (2000). One Money, One market: Estimating the Effect of Common Currencies on Trade. Economic Policy, 30. http://dx.doi.org/10.1111/1468-0327.00056

Sachs, J., \& Warner, A. (1995). Economic Reform and the Process of Global Integration. Brookings Papers on Economic Activity.

Smith, C. (2002). Currency Unions and Gravity Models Revisited, Reserve Bank of New Zealand. Discussion Paper Series.

Ukaoha, K. (2008). Le TEC de la CEDEAO: Les impératifs de la cinquième bande du Nigeria. Eclairage sur les négociations, Ictsd-Ecdpm, 7(4).

Winters, A., McCulloch, N., \& Mckay, A. (2004). Trade Liberalization and Poverty: The evidence so far. Journal of Economics Literature, 42(1), 72-115. http://dx.doi.org/10.1257/002205104773558056

\section{Copyrights}

Copyright for this article is retained by the author(s), with first publication rights granted to the journal.

This is an open-access article distributed under the terms and conditions of the Creative Commons Attribution license (http://creativecommons.org/licenses/by/4.0/). 